\title{
Gereformeerde identiteit vandag? Ontwikkelings en rigtings
}

\begin{abstract}
The paper pays tribute to the honouree by offering a case study of one of the key themes of Brümmer's later research, namely the identity of traditions. It provides an overview of diverse answers to questions about Reformed identity. In a first section, it is argued that this rich diversity of responses to the identity question is in itself already typically Reformed, since it is caused by several Reformed characteristics. The second section sets the scene for the different answers with a brief overview of the contemporary Reformed landscape. The final four sections then serve as reminders of four well-known but different ways of approaching the question. The third section discusses issues regarding the Reformed community as a confessional tradition. The fourth section focuses on Reformed doctrine. The fifth section considers the Reformed way of life and the final section deals more specifically with the question whether there is something like a characteristic Reformed ethics.
\end{abstract}

\section{GEREFORMEERDE IDENTITEIT?}

Vincent Brümmer het self deur die jare toenemend' $n$ belangstelling ontwikkel in konseptuele vrae rondom tradisie - rondom die aard van tradisies, waarin die identiteit van tradisies ten diepste geleë is, waarin die kontinuïteit van tradisies sou bestaan, wie die legitieme verteenwoordigers en dus uitleggers van tradisies is, waar en hoe die grense van tradisies bepaal kan word, en vele verwante vrae.

In die inleidende "Meanders in my Thinking: A Brief Intellectual Autobiography" in sy Collected Essays. Brümmer on Meaning and the Christian Faith vertel hy self van dié ontwikkelinge. "After 1976 ... I defended the view that systematic theology itself could be seen as a form of conceptual analysis exploring the assumptions and implications of basic doctrinal concepts in the Christian tradition."2

Toenemend sou hy ook, vertel hy, daarmee begin rekening hou dat die geloof nie 'n geslote denksisteem is waarvan die inhoud as konsepte beskou en geanaliseer kan word nie, maar eerder' $n$ lewende tradisie. "During the 1980s ... I also began to realize that the meaning (of the Christian Faith, DJS) is not timelessly fixed ... not a closed system of thought but a tradition in which the heritage of faith is continually being reinterpreted to keep it relevant and adequate to the ever-changing demands of life." 3

Met dié groeiende insig sou ook sy siening van die taak van die teologie ander beklemtonings begin ontvang. "The task of the theologian is therefore not to describe a fixed system of thought

1 Die betrokke opstel is 'n verwerking van die oorspronklike "Kronkels in mijn Denkweg," in Gijsbert van den Brink, Luco J. van den Brom \& Marcel Sarot (Reds), Wijsgerige Theologie in Beweging, Utrecht: Rijksuniversiteit, 1992, 7-27. Dit is daarna in verwerkte vorm in Engels gepubliseer as "Meanders in my Thinking: A Brief Intellectual Autobiography" in sy Collected Essays. Brümmer on Meaning and the Christian Faith, Aldershot: Ashgate, 2006, 3-27.

2 Brümmer 2006, 17.

3 Brümmer 2006, 18. 
like an ideology, but to produce creative proposals for re-conceptualising the heritage of faith in ways that are adequate and relevant to the lives of believers."4

Verskeie van die terme in hierdie beskrywings (van tradisie en van die taak van teologie) sou sleutelterme in sy denke en werk word, wat hy toenemend sou bedink en verduidelik, maar ook telkens by wyse van illustrasie sou toepas.

Hy wy dan ook sy afskeidsrede in Utrecht aan die einde van 1997 aan hierdie tema, onder die opskrif "The identity of the Christian tradition." Oudstudente organiseer daarby'n internasionale konferensie in gesprek met hom oor dié tema, wat gepubliseer word as Identity and Change in Religious Traditions. ${ }^{5}$

In dié rede gaan hy veral in op die feit dat lewende tradisies pluralisties en veranderlik van aard is. Dit geld ook van meet af van die Christelike tradisie, as ' $n$ lewende tradisie. Reeds reg vanaf die begin - soos die neerslag in Nuwe Testamentiese geskrifte toon - is daar klaarblyklik sowel veelvoud as nuutheid, en albei aspekte is integraal tot die aard van hierdie tradisie. Die tradisie en die geloof leef daarvan.

Hierdie tradisie is gevolglik "not timelessly immutable but constantly require(s) translation, re-conceptualisation and re-interpretation in order to maintain their relevance and adequacy, as well as their intelligibility and credibility." In sy afskeidsrede gaan hy dan op die (moontlike, dog omstrede) betekenisse van hierdie vier terme verder in, te wete relevansie, toereikendheid, verstaanbaarheid en geloofwaardigheid.

In die lig van dié teoretiese raamwerk dink hy dan na oor die hermeutiese uitdagings verbonde aan só ' $n$ siening van die geloof as 'n lewende tradisie en aan die uitdagings vir die teologie wat daaruit volg. Hy vra waarin die eenheid en die identiteit van so 'n (veelvoudige en veranderende) tradisie dan kan bestaan, en oorweeg verskillende moontlike antwoorde, te wete een of ander soort siening van essensie, een of ander soort kontinuïteit en een of ander soort verband met die oorspronge van die tradisie.

Sy gevolgtrekkings word duidelik saamgevat. "We can now conclude that the unity and identity of the Christian tradition can be found in the narrative continuity of the historical process of interpretation that starts in the Bible itself and refers to the connected series of events telling of the impact of Jesus Christ, who is acknowledged by believers to be the fixed origin of the tradition as well as the paradigmatic locus of meaning for human existence. The heritage that is passed down from generation to generation in this tradition is however by no means timelessly immutable, but requires constant translation, re-conceptualisation and re-interpretation in the light of the ever changing demands of life confronting participants in the tradition" (my kursivering, DJS). ${ }^{6}$

In dié lig kan hy ook die taak van die teologie beskryf. "(T)he Christian heritage is handed down to us in fluid form, retaining the ability to change and to become new versions of itself. For this reason the Christian tradition is not dead but alive. It is the task of theologians to keep it so by creatively sustaining and developing our understanding of the original exemplar's achievement in ways that remain relevant, adequate, intelligible and credible in the ever changing context where we humans are called upon to live and move and have our being" (my kursivering, DJS). ${ }^{7}$

\section{Brümmer 2006, 18.}

5 Marcel Sarot \& Gijsbert van den Brink (Reds), Identity and Change in the Christian Tradition, Frankfurt: Peter Lang, 1999. In dié bundel verskyn sy opstel op bladsye 23-42. Dit is egter ook opgeneem in Brümmer, Collected Essays. Brümmer on Meaning and the Christian Faith, Aldershot: Ashgate, 2006, 375-390.

6 Brümmer, Collected Essays. Brümmer on Meaning and the Christian Faith, Aldershot: Ashgate, 2006, 389.

7 Brümmer, Collected Essays. Brümmer on Meaning and the Christian Faith, Aldershot: Ashgate, 2006, 390. 
Sy huidige navorsing kan beskou word as 'n gevalle-studie van dié soort benadering, op 'n klein skaal. Hy is naamlik besig om die soms dramatiese teologiese ontwikkelinge aan die Stellenbosse Seminarie vanaf die laat 19 de tot die vroeg 20 ste eeue te beskryf. Hy doen dit in die vorm van só 'n narratief, rondom die vraag hoe - wat hy noem - tradisies van "vroomheid" en van "regsinnigheid," op komplekse wyses verteenwoordig en verwoord deur verskillende invloedryke figure, telkens met mekaar in spanning was, en hoe dié voortslepende stryd die identiteit van die tradisie aan hierdie inrigting voortdurend en opnuut sou beïnvloed.

In huldiging van sy lewenswerk word die volgende gedagtes aan hom gewy, eweneens as 'n soort gevalle-studie van hierdie aard, te wete rondom die vraag hoe die identiteit van die Gereformeerde identiteit en tradisie vandag wêreldwyd beskryf sou kon word, met Brümmer se insigte en oortuigings in ag genome.

Die vraag na Gereformeerde identiteit is immers blywend 'n aktuele en 'n uiters ingewikkelde vraag. Oor ongeveer 'n dekade vind daar tans verskeie herdenkings wêreldwyd plaas van gebeurtenisse, figure en dokumente wat almal vroeg reeds fundamentele bydraes gemaak het tot die beweging wat as die Gereformeerde gemeenskap sou ontwikkel en groei.

In 2009 was daar oraloor herdenkings van Calvyn se geboorte, ook in Suid-Afrika. Kongresse is gehou, navorsing is gedoen en publikasies het verskyn. In 2011 is die ontstaan van die Nederlandse Geloofsbelydenis (of Confessio Belgica) in herinnering geroep, en weer eens het verskeie gebeurtenisse daaromheen plaasgevind, hier plaaslik, maar ook in Brussel, naby die ontstaansoord van dié invloedryke dokument. In 2013 sal die ontstaan van die Heidelbergse Kategismus onthou word, sonder twyfel dié vroeë Gereformeerde belydenis dokument wat die mees ekumeniese resepsie en werkingsgeskiedenis sou ontvang, tot vandag. Op vele maniere en in wye kringe het dié geskrif geloof, spiritualiteit en lewe beïnvloed en help stempel. In 2017 word die gebeure van Wittenberg gebruik as oriëntasiepunt om die hele Reformasie aan te koppel. Uiteraard sal die Gereformeerde tradisie en gemeenskap dan slegs as onderdeel van ' $n$ groter historiese beweging ter sprake kom, maar sonder twyfel sal die aandag tog ook weer wees op dié bydrae te midde van die groter kerklike en sosiale ontwikkelinge. In 2018-2019 behoort die Sinode van Dordrecht en die - tegelyk omstrede én hoogs gerespekteerde - Leerreëls aan die beurt te wees, ten minste in die kerke gebore vanuit dié enger Nederlandse omgewing.

Tydens dié prosesse word die vrae onvermydelik telkens weer gestel rondom die Gereformeerde identiteit - of daar inderdaad so iets is en waarin dit sou bestaan. Die antwoorde op dié soort vrae word gekompliseer deur die talryke ontwikkelinge wat al sedert die aanvangsjare plaasgevind het, maar ook deur die vele rigtings wat sou groei en tans steeds naas mekaar bly bestaan - van vroomheid, oortuiging, gestalte en lewe. ${ }^{8}$

Dit is algemeen bekend dat dit baie moeilik is om Gereformeerde teologie te omskryf, vanweë redes wat te doen het met die aard van Gereformeerde teologie self. Terselfdertyd fassineer dié vraag Gereformeerdes dikwels, en die interne gesprekke oor die identiteit van die tradisie hou nooit op nie. Hierdie pogings begin dikwels met ' $n$ verduideliking van waarom dit so 'n onmoontlike taak is, en in dié proses beskryf hulle alreeds belangrike eienskappe van die Gereformeerde geloof en teologie. ${ }^{9}$

8 Die kern van hierdie bydrae berus op 'n opstel wat oorspronklik op uitnodiging vir die The Expository Times geskryf is, as deel van 'n reeks oor konfessionele en hedendaagse teologiese tradisies en strominge. Die oorspronklike titel was "Trends and Directions in Reformed Theology," The Expository Times 122, Vol 7 April 2011, 1-14. Ander bydraes in die reeks het byvoorbeeld gehandel oor liberale teologie, pluralistiese teologie, postliberale teologie, feministiese teologie, Anglikaanse teologie, Radikaal Ortodokse teologie, Katolieke teologie (Fergus Kerr), politieke teologie (Tim Gorringe), analitiese teologie (Oliver Crisp), en Ortodokse teologie, met 'n afsluitende oorsig deur David Fergusson.

9 Sien byvoorbeeld die drie insiggewende oorsigte met opstelle, Michael Welker en David Willis (reds.),

Toward the Future of Reformed Theology: Tasks, Topics, Traditions, Grand Rapids: Eerdmans, 1998; 
Hulle onderstreep die enorme uiteenlopendheid van die Gereformeerde tradisie. Daar was die kenmerkende sosiale, linguistiese, kulturele, politieke diversiteit sedert die begin in die 16de eeu. Daar was die bewuste konfessionele uiteenlopendheid sedert die vroegste tye, sonder enige poging om 'n universele belydenis daar te stel. Daar was die hermeneutiese diversiteit as gevolg van die belangrike rol wat die Skrif as finale gesag in alle sake rakende geloof en lewe speel, wat dikwels beskryf is as die sola scriptura-beginsel wat die Gereformeerde geloof meer as enige iets anders kenmerk. Daar was die ekklesiologiese diversiteit as gevolg van die gebrek aan sterk gesag- of hiërargiese strukture. Daar was die historiese diversiteit, omdat Gereformeerde kerke so geneig is om diep betrokke te raak by bepaalde sosiale en kulturele kontekste. Daar was 'n etiese diversiteit, omdat die Gereformeerde geloof tipies daarna strewe om vergestalting te vind in die morele, openbare en politieke lewe, en daarom onvermydelik deel word van baie nuwe ontwikkelings en nuwe werklikhede.

In 'n poging om gevolglik te onderskei wanneer die grense van legitieme pluraliteit oorskry word, word die Gereformeerde geloof daarom ook gekenmerk deur voortdurende selfondersoek oor vrae rondom identiteit en grense. Natuurlik is grense met betrekking tot ál hierdie vorme van diversiteit voortdurend getrek - byvoorbeeld kulturele grense, wat sosiale, linguistiese en politieke grense (hetsy gebaseer op nasie, volk of ras) sou insluit, soms selfs deur ander uit te sluit; konfessionele grense, wat dikwels (slegs) groepe se eie belydenisdokumente as ortodoks, waar en gesaghebbend sou beskou; hermeneutiese grense, wat op afdoende interpretasies van die Skrif aanspraak maak en maklik tot standpunte van stelligheid, onfeilbaarheid en fundamentalisme sou lei; ekklesiologiese grense, wat talle verdelings en afskeidings tussen nuutgestigte kerke teweeg sou bring; historiese grense, wat dikwels ernstige konflikte en verdelings binne en tussen kerke sou veroorsaak; etiese grense, wat op geestelike, morele, etiese en politieke verskille gebaseer is. Die tradisie is om presies al dié redes selfs al beskryf as bound to differ - geneig om te verskil, bestem om te verskil, selfs aan mekaar verbonde deur al dié onderlinge geskille en verskille. ${ }^{10}$

Die beskrywing "Gereformeerd" verwys egter ook alreeds na 'n verdere kenmerk wat die verhaal nog selfs ingewikkelder maak, naamlik'n selfkritiese bewussyn wat voortdurend na nuwe vorme van gehóórsaamheid soek en juis dáárom tot sy eie steeds veranderende, vernuwende, transformerende aard bydra. Hierdie eienskap word goed opgesom in die populêre gesegde dat "'n Gereformeerde kerk gedurig reformeer in ooreenstemming met die Woord van God". Dit is inderdaad só dat verreikende en ingrypende historiese skuiwe binne die kerke wat tot hierdie tradisie behoort, waargeneem kan word. Die tradisie is besonder gevoelig vir konteks en historiese ontwikkelings. Die Gereformeerde geloof is dikwels verantwoordelik gehou - hetsy geprys of geblameer, geloof of verwyt! - vir sy bydrae tot belangrike historiese veranderings, byvoorbeeld tot die ontstaan van moderniteit en die moderne lewe, maar terselfdertyd is dit self in die proses diepgaande beïnvloed en getransformeer deur hierdie historiese krisisse en ontwikkelings. ${ }^{11}$

Wallace M Alston en Michael Welker (reds.), Reformed Theology: Identity and Ecumenicity, Grand Rapids: Eerdmans, 2003; Wallace M Alston en Michael Welker (reds.), Reformed Theology: Identity and Ecumenicity II, Grand Rapids: Eerdmans, 2007.

10 Wesley A. Kort, Bound to Differ, University Park: Pennsylvania State, 1992.

11 Sedert die stellings van Max Weber en Ernst Troeltsch het geleerdes oor die invloed van Protestantisme, en spesifiek die Calvinisme, nagedink met betrekking tot die ontstaan en vorming van die moderne wêreld - die wêreld van die vryemark-ekonomie; van demokratiese kultuur en die openbare lewe; oor die skeiding van kerk en staat in die liberale politieke lewe; oor 'n sekulêre tydperk; oor die oppergesag van die reg en die onafhanklikheid van die regterlike stelsel van sowel staat as godsdiens; die wêreld wat op hedendaagse vryhede gebou is; oor die kernwaardes van menswaardigheid en menseregte; oor verreikende rasionalisasie en die verspreiding van opvoeding, wetenskap, navorsing en kennis as basis 
Die gevolg is dat die verhaal van die Gereformeerde geloof in enige spesifieke gemeenskap vandag nie net 'n verhaal van uiteenlopendheid, selfs van stryd en konflik is nie, maar ook van verandering, selfs waar sommige hartstogtelik probeer om vas te kleef aan ononderbroke kontinuïteit. Daarom is dit in beginsel onmoontlik om konsensus oor enige beskrywing van Gereformeerde teologie te bereik. Enige skets sal uiters subjektief bly en oop vir kritiek, meningsverskil en teenoorgestelde aansprake. Die Gereformeerde verhaal is inderdaad ' $n$ verhaal van vele verhale.

\section{DIE GEREFORMEERDE LANDSKAP?}

Alreeds sedert die vroegste begin was die Gereformeerde tradisie 'n komplekse en uiteenlopende, selfs ambivalente, beweging. Dit het tegelykertyd in verskeie Switserse stede en gemeenskappe ontstaan en ontwikkel (Zürich 1519; Basel 1528; Genève 1535/36), rondom 'n verskeidenheid invloedryke leiers - wat Johannes Calvyn (1509-1564) in Genève insluit, maar óók vormende figure soos Zwingli, Bullinger, Oecolampadius, Beza en baie ander. Dit is in baie verskillende lande ondersteun en het ' $n$ verskeidenheid plaaslike vorms aangeneem. ${ }^{12}$ Dit was 'n belydenistradisie sonder enige sentrale gesagstrukture wat eenvormigheid oor geloofsake, beleid en lewe kon bepaal. Selfs die geloofsbelydenisse - en die plaaslike kerkordes wat dikwels hierdie geloofsbelydenisse weerspieël het - was uiteenlopend en plaaslik.

Vandag het dit die verhaal geword van ontwikkelings in baie verskillende lande en kontinente, byvoorbeeld Switserland, Frankryk, Italië en Duitsland; maar ook Nederland en België en baie kerke wêreldwyd wat deur die Nederlandse kerklewe en teologie beïnvloed is; Brittanje, veral Skotland, en weer eens baie kerke onder die invloed van die kerklewe en teologie in hierdie samelewings; kerke in verskeie streke in Sentraal- en Oos-Europa, wat veral Hongarye en nog verskeie ander insluit; die Verenigde State van Amerika en Kanada en hulle invloedryke teenwoordigheid in baie dele van die wêreld; baie kerke in Afrika, insluitende Wes-, Sentraalen Suid-Afrika; kerke, insluitende groot en groeiende kerke in baie samelewings in Asië en Australasië, byvoorbeeld Indonesië en Korea, benewens baie ander; en sommige streke in Latyns-Amerika. Twee-derdes van alle Gereformeerde Christene vandag woon in Asië, Afrika en Latyns-Amerika. ${ }^{13}$

Dit is eenvoudig onmoontlik om die verhaal van Gereformeerde teologie op 'n manier te vertel wat reg sal laat geskied aan hierdie rykdom, kompleksiteite en dubbelsinnighede. Die meeste van hierdie kerke is lid van die Wêreldgemeenskap van Gereformeerde Kerke (WGGK) wat die resultaat is van die samesmelting tussen die Wêreldbond van Gereformeerde Kerke (WBGK) en die Gereformeerde Ekumeniese Raad (GER) in Junie 2010 te Grand Rapids. Hierdie liggaam sluit meestal kerke in met Calvinistiese, Presbiteriaanse, Kongregasionalistiese en Verenigde agtergronde, maar ook verskeie ánder met uiteenlopende historiese agtergronde,

vir die gemeenskapslewe; oor 'n sterk sin vir moraliteit, roeping en verantwoordelikheid wat manifesteer in alledaagse arbeid en openbare dienslewering. Weer eens is die meeste van hierdie historiese stellings kontroversieel en betwis, maar dit maak die beskrywing van Gereformeerde teologie net nog ingewikkelder.

12 Vir kort maar ingeligte inleidings, sien byvoorbeeld die toepaslike opstelle in Carter Lindberg (red.), The Reformation Theologians, Oxford: Blackwell, 2002, veral 155-266 en David Bagchi en David C. Steinmetz (reds.), The Cambridge Companion to Reformation Theology, Cambridge: Cambridge Universiteit, 2004, veral 80-193.

13 Sien Jean-Jacques Bauswein en Lukas Vischer (reds.), The Reformed Family Worldwide: A Survey of Reformed Churches, Theological Schools and International Organizations, Grand Rapids: Eerdmans, 1999, veral die baie leersame opstel deur Vischer, "The Reformed Tradition and its Multiple Facets", $1-33$. 
waar onder byvoorbeeld ook die Waldensiane en Boheemse Broeders. Hierdie kerke deel nie enige gemeenskaplike belydenistradisie of enige gesagstruktuur wat identiteit en eenvormigheid sou kon waarborg nie.

Die spesifieke verhale van hierdie verskillende kontekste dra slegs verder by tot die gevarieerde en komplekse prentjie. ${ }^{14}$ Die vormende ontwikkelings en gebeure en die verteenwoordigende en invloedryke figure en denkers vorm deel van hierdie verskillende verhale - name uit latere generasies, soos Francis Turretin (1623-1687), Friedrich Schleiermacher (1768-1834), Jonathan Edwards (1703-1758), Charles Hodge (1797-1878) en Benjamin Warfield (1851-1921), Karl Barth (1886-1968) en Emil Brunner (1889-1966), Reinhold (1892-1971) en H Richard Niebuhr (1894-1962), John (1886-1960) en Donald Baillie (1887-1954), Thomas F (1913-2007) en James Torrance (1923-2003). Net hierdie kort en baie arbitrêre lys name - wat bewustelik aktiewe Gereformeerde teoloë vanoor die hele wêreld uitsluit - demonstreer alreeds die wye verskeidenheid posisies en tradisies binne die Gereformeerde geloof.

Bram van de Beek se vertelling oor die hoofstroom Gereformeerde Kerke in Nederland bied ' $n$ insiggewende voorbeeld. ${ }^{15} \mathrm{Hy}$ beklemtoon die noue verband tussen Gereformeerde teologie en die hedendaagse kultuur. Dit was die belangrikste kwessie op verskillende tye van ontwikkeling in Nederland in die 19de en 20ste eeu. Die reaksies op 'n bepaalde tydstip kon wyd verskil, wat die kompleksiteit van die verhaal verklaar, maar hierdie sensitiwiteit vir die tydsgees bly konstant in sy vertelling. Die Nederlandse Hervormde Kerk het hom altyd as ' $n$ nasionale kerk gesien, redeneer hy, selfs nadat politieke veranderinge ' $n$ offisiële einde hieraan gebring het. Aan die begin van die 20ste eeu het die leidende Gereformeerde teoloë (Kuyper, Bavinck, later Schilder en nog later Berkouwer) nie uit hierdie kultureel goed-aangepaste kerk gekom nie, maar uit die meer konfessionele kerke wat in die 19de eeu weggebreek het. Hy verdeel die 20ste eeu in drie tydperke. In die eerste tydperk, tot by die einde van die Tweede Wêreldoorlog, het "die mees fassinerende teoloë uit daardie tyd" (Noordmans, Gerretsen) buite die akademie en buite "die georganiseerde oortuigings van daardie tyd" gewerk. Dit is insiggewend hoe Van de Beek hulle as die ware verteenwoordigers van die Reformasie beskryf. Hulle verteenwoordig "'n kritiese stroom" wat veral "in krisistye" tot "nuwe kreatiwiteit" kan lei. "Actually they are the treasurers of the heritage of the Reformation ... Figures like (they) are Reformed in a deep, persisting undercurrent. Theirs is a Reformed theology which never gives us rest in ourselves". In 'n tweede tydperk, van 1945 tot 1980, verander die prentjie drasties. Die baie bekende Nederlandse Hervormde teoloë uit die 20ste eeu het nou hulle bloeitydperk beleef (wat Miskotte, Kraemer, Visser 't Hooft, Hendrikus Berkhof, Van Ruler, Van der Leeuw en Ter Schegget insluit). Volgens hom is "hulle almal aangevuur deur dieselfde visie: 'n verchristelikte gemeenskap volgens

14 Sien byvoorbeeld twee nuttige versamelings opstelle oor Gereformeerde teologie in baie verskillende lande, Acta Theologica, Volume 12, nr. 1, Julie 1992, spesiale uitgawe, red. S D (Fanie) Snyman, met opstelle oor Amerika (deur Migliore), Australië (De Waard), Kanada (Van Dam), Nederland (Velema), Skotland (T A Hart) en Suid-Afrika (Smit); ook George Harinck en Dirk van Keulen (reds.), Vicissitudes of Reformed Theology in the Twentieth Century, Studies in Reformed Theology Volume 9, Zoetermeer: Meinema, 2004, wat naas baie ander, artikels insluit oor Switserland (deur Zangger), Duitsland (Plasger), Brittanje (Sell), Transilvanië (Gudor en Foka van de Beek), Neo-Calvinisme in Noord-Amerika (Bolt), Presbiterianisme in die Verenigde State (D G Hart) en Korea (Kim).

15 Bram van de Beek, "A Christianized Society according to Reformed Principles", Vicissitudes (sien vorige noot), 69-86. Dis reeds op insiggewend dat die bundel ook ander opstelle oor ander Gereformeerde kerke in Nederland bevat (Van Keulen; Kamphuis), wat ook die geval is met die meeste ander opstelle, omdat hulle die verhaal van baie kerke in 'n spesifieke samelewing moet vertel, dikwels met uiteenlopende vormende gebeure, invloedryke figure, kernontwikkelings en leidende teoloë. Allan Sell vertel byvoorbeeld die verhaal "to cover the writings of scholars who belonged, or belong, to one or other of the fifteen Reformed Churches or unions currently to be found in the British Isles, or their predecessor bodies", 130. 
Gereformeerde beginsels". Sy (kritiese) punt is duidelik. Baie van hulle was in die sending en getuienis vir die koninkryk geïnteresseerd, in sosiale en politieke betrokkenheid, in hernuwing, selfs verbetering van die wêreld, in die aktiwiteite van die (destydse) ekumeniese beweging. Hy merk op dat dit nie "sonder rede" was dat die stigtersvergadering van die Wêreldraad van Kerke in Amsterdam was nie. Tog kan daar skynbaar skrille verskille tussen hulle heers. Hulle kan òf optimisties wees (met Berkhof se Christian Faith as die "kroonjuweel") òf duidelik krities (met 'n neiging tot sosialisme), maar diep binne-in stem hulle saam dat die kerk weet wat goed is vir die wêreld. Baie mense sou hulle as (tipies) Gereformeerd beskou (en dit lyk of hulle saamstem met die latere Barth van die 1946-brosjure oor Christengemeinde und Bürgergemeinde), maar Van de Beek verskil diepgaande van hierdie populêre siening. Gedurende al hierdie tydperke, redeneer hy, het die Nederlandse Hervormde Kerk eintlik maar net die veranderings in die Nederlandse kultuur en gemeenskap nagevolg en weerspieël. Presies dieselfde sou nogeens in ' $n$ derde tydperk, wat in die laaste twee dekades van die vorige eeu begin het, gebeur, toe die kerk 'n klein en onbeduidende minderheid in Nederland geword het. Volgens hom is die kerk nou met ' $n$ volledig nuwe situasie gekonfronteer, een wat hy vir meer as 'n millennium nie geken het nie, en een waarvan hy nie weet hoe om dit te hanteer nie. In hierdie situasie van radikale Nederlandse sekularisasie en ' $n$ diepliggend ateïstiese moderne kultuur, kies Van de Beek self vir 'n teologie wat die kerk as vreemdelinge in die wêreld beskou, as uitheemse inwoners. Hy beweer weer dat so 'n benadering mag lyk asof dit wegbeweeg van tradisionele Gereformeerde teologie, maar dit verteenwoordig inderwaarheid die werklike Gereformeerde tradisie: "in hierdie posisie draai ek weg van tradisionele Nederlandse Gereformeerde kulturele- en sosiale teologie, (maar) in hierdie teologie kom die klassieke ondertoon van die Reformasie weer eens te voorskyn". In sy vertelling kom die problematiek om Gereformeerde teologie te beskryf duidelik na vore, want elke figuur en groep in die verhaal beskou hulle as die ware erfgename van die Gereformeerde gees, hoe teenstrydig hulle posisies ook al mag wees.

Baie meer verhale sou natuurlik vertel kon word oor Gereformeerde teologie en ander historiese kontekste waar Gereformeerde, Presbiteriaanse en Kongregasionalistiese kerke en teoloë belangrike rolle gespeel het - insluitende byvoorbeeld Switserland en Duitsland, Hongarye, Transilvanië en ander plekke in Oos-Europa, Brittanje en veral Skotland, die Verenigde State van Amerika en Kanada, Suid-Afrika en verskeie ander Afrika-lande, Korea en verskeie ander Asiatiese lande. Maar om die historiese prentjie net meer volledig te skets sal nog nie die vraag na die eienskappe van die tradisie self beantwoord nie.

\section{DIE GEREFORMEERDE BELYDENISTRADISIE?}

In die soeke na sulke eienskappe is die Gereformeerde tradisie dikwels beskryf as ' $n$ belydenistradisie. Geloofsbelydenisse het 'n uiters belangrike rol gespeel in die definiëring van die tradisie, en was deurslaggewend waar Gereformeerde kerke in hulle onderskeie omgewings hulle as lede van die katolieke kerk gesien het en hulle begrip van die een evangelie vir hulle tyd en omstandighede probeer verwoord en beliggaam het. ${ }^{16}$ Van die begin af het die tradisie 'n veelvoud aan belydenisdokumente. Dit het kenmerkend geword om met veelvuldige belydenisdokumente te lewe. Die veelvuldigheid aan dokumente is boonop vergesel deur ' $n$

16 Vir 'n standaard versameling van sommige van die vroegste Gereformeerde belydenisse, sien E F Karl Müller, Die Bekenntnisschriften der reformierten Kirche, Leipzig: A Deichert, 1903; vir 'n meer onlangse versameling, Georg Plasger en Matthias Freudenberg, Reformierte Bekenntnisschriften, Göttingen: Vandenhoeck \& Ruprecht, 2005. Vir waardevolle inleidings tot die komplekse ontwikkelings van hierdie belydenisse, sien Lukas Vischer, "The Reformed tradition and its multiple facets", in Jean-Jacques Bauswein en Lukas Vischer, The Reformed family worldwide: A survey of Reformed churches, theological schools and international organizations, Grand Rapids: Eerdmans, 1999, 1-33. 
veelvuldigheid aan standpunte oor hulle aard en gebruik - 'n veelvuldigheid wat dikwels tot dispute en konflikte gelei het. Merkwaardige verskille in standpunte en praktyke wat betref belydenisdokumente kan gesien word tussen - byvoorbeeld - die Switserse, Duitse, Hongaarse, Skotse en Nederlandse kerke, verskille wat slegs vermenigvuldig word as Gereformeerde kerke in Afrika, Asië, die Amerikas en die Presbiteriaanse en Kongregasionele wêrelde ook in ag geneem word. Dit bring die vrae rondom die bindende aard van Gereformeerde belydenisse na vore.

Onder normale omstandighede - vir die meeste Gereformeerde kerke - besit belydenisdokumente ' $n$ relatiewe gesag, met die klem op albei die terme. Hulle het gesag, want hulle verteenwoordig die manier waarop vroeëre geslagte die Woord van God verstaan het. Hierdie gesag is egter relatief, eerstens omdat sulke belydenisse in beginsel altyd onderworpe is aan die finale gesag van God se Woord, tweedens omdat hulle histories is, en derdens omdat hulle die produkte van feilbare mense is, en daarom in beginsel altyd hersien kan word. Hierdie erkenning van hulle relatiewe gesag en dus hersienbare aard word deur sommige as kenmerkend van die Gereformeerde posisie beskou. Al drie hierdie redes verteenwoordig tipiese Gereformeerde oortuigings.

In die eerste plek is Gereformeerde belydenisse altyd onderworpe aan die gesag van God se Woord. Hulle dra geen gesag in en uit hulleself nie, en verder ontvang hulle ook nie gesag vanuit enige eksterne bronne of faktore van gesag, byvoorbeeld die gesag van die kerkleiers wat hulle uitspreek nie, of die kerklike gesag wat hulle aankondig nie, of die kerklike vergaderings wat hulle aanvaar nie. Soms word hulle norma normata genoem ter onderskeiding van die norma normans, genormeerde norme in teenstelling tot die normerende norm, of ook "ondergeskikte standaarde". Baie sluit 'n eksplisiete uitnodiging in om hulle te meet aan die boodskap van God se Woord en ' $n$ belofte dat hulle hersien, aangepas of verwerp sal word wanneer dit aangetoon kan word dat dit nodig is.

In die tweede plek is Gereformeerde belydenisse histories en kontekstueel van aard. Hulle moet op ' $n$ verantwoorde manier geïnterpreteer word - met respek vir hulle historiese konteks en sosiale en kulturele agtergrond, sensitiwiteit vir die grammatikale en konseptuele instrumente waaroor die oorspronklike skrywers beskik het, versigtige insig in die spesifieke teenstrydighede waarbinne en die posisies waarteen hulle in die eerste plek geskryf is, 'n gevoel vir die retoriese doelstellings, dryfkrag en impak van die oorspronklike argument. Hulle is nie a-historiese dokumente met tydlose en ewige stellings nie. Telkens wanneer dit geïgnoreer is, het dit gelei tot standpunte en praktyke wat fundamentele Gereformeerde oortuigings weerspreek en selfs verloën het - die waarheid het maklik die akkuraatheid van stellings geword; geloof het intellektuele gehoorsaamheid aan gesaghebbende dokumente, vergaderings, besluite of figure geword, die kennis van die geloof het intellektuele inligting oor historiese feite en korrekte formulerings geword, sekerheid het rasionele gevolgtrekkings geword wat op onweerlegbare aksiome gebaseer is, gesag het in die eerste instansie institusioneel en wetlik geword, Gereformeerde belydenisse het self denkstelsels geword wat gebruik kon word om mense wat nie aan hulle presiese uitdrukkings en formulerings trou is nie, te dissiplineer. Baie Gereformeerde kerke is deur sulke konflikte uitmekaar geskeur. Vir hoofstroom Gereformeerde vroomheid het belydenisse egter intense eksegese en interpretasie nodig. Dit is juis as historiese en kontekstuele dokumente, teen die agtergrond van hulle eie debatte, versoekinge, konflikte en worstelinge dat hulle hulle gesag vir die hede behou.

In die derde plek is Gereformeerde belydenisse die produkte van feilbare menslike aktiwiteit, wat beteken dat dit nodig mag wees vir korreksies, hersiening en selfs vervanging. Die belydenistradisie waarsku self dikwels teen oorskatting van enige vorm van menslike besluitneming, standpunte, vergaderings en dokumente - wat hulleself uiteraard insluit. Dit geld ook vir die kerkvergaderings waar hierdie dokumente bespreek en aangeneem is, vir al die teoloë 
in die tradisie, en vir alle leiersfigure, skole, besluite - alles feilbare werk van mense. Dit beteken nie dat hierdie belydenisse bloot as die persoonlike menings van hulle wat daarby betrokke was of bloot die perspektief van 'n bepaalde kerk, gelowiges or gemeentes gesien moet word nie, inteendeel. Die tradisie is nie geïnteresseerd om "Gereformeerde" of "Calvinistiese" standpunte en leringe daar te stel en te verdedig nie. Diep bewus van hulle eie menslike beperkings en perspektiwiteit, beweer hulle steeds dat hulle die evangelie bely vir hulle eie bepaalde konteks. Gereformeerde belydenisse is daarom altyd aan die algemene katolieke kerk gerig, hulle strewe altyd na ekumenisiteit. Daarom gee hulle die geleentheid vir response van die broeders en susters, nie om die belydenisdokumente as hulle eie te aanvaar nie, maar om aan te dui dat hulle dieselfde oortuigings het ten opsigte van die evangelie, of nie. Dit is wat die verdere resepsieproses so belangrik maak - nie altyd die aanvaarding as belydenisdokumente met enige status nie, maar primêr ontvangs in die vorm van erkenning, van studie, nadenke, bespreking, kritiek, gebruik, en as bron van inspirasie met die oog op verdere aksie.

Saam beskou, impliseer hierdie drie eienskappe dat dit onder spesifieke omstandighede vir die kerk nodig mag word om opnuut te bely. Onder abnormale omstandighede, wanneer hulle gekonfronteer word met radikale uitdagings aan die evangelie, mag sulke Gereformeerde kerke daarom voel dat hulle belydenis self, die integriteit en geloofwaardigheid van hulle getuienis op die spel is. ${ }^{17}$ Saam met ander Protestantse kerke beskryf Gereformeerde kerke sulke abnormale omstandighede van uitdaging en krisis met die uitdrukking status confessionis, wat aandui dat 'n oomblik van waarheid aangebreek het waarin die waarheid van niks anders as die evangelie self op die spel is nie. Die WBGK het ' $n$ beskrywing van ' $n$ status confessionis gegee tydens die vergaderings in Seoul en Debrecen. ${ }^{18}$ Soms mag kerke tydens 'n status confessionis die behoefte hê om hulle geloof opnuut uit te druk, hoewel dit nie noodwendig hoef te gebeur nie. In die 20ste eeu het dit by 'n paar geleenthede en in verskillende omstandighede gebeur (byvoorbeeld Barmen in Nazi-Duitsland en Belhar in apartheid Suid-Afrika). ${ }^{19}$

Deur die eeue was daar inderdaad ' $n$ aantal pogings om die pluraliteit te verminder, deur òf sekere Gereformeerde belydenisse met mekaar in 'n enkele stel leringe te verenig, òf deur die inhoud van die hoofbelydenisse te vergelyk en te verminder na 'n gesaghebbende versameling Gereformeerde lerings en oortuiginge, óf selfs om een universele Gereformeerde belydenis te skryf en om maniere te vind om 'n soort algemene gesag aan so 'n belydenis toe te ken. In die laat 19de eeu, tydens die vroeë jare van die (latere) WBGK, is sulke voorstelle dikwels gemaak, maar altyd na besprekings verwerp. ${ }^{20}$ Nie een van hierdie pogings het enige ernstige belangstelling of ondersteuning in Gereformeerde kringe ontlok nie. Hulle het almal die eintlike aard van Gereformeerd wees weerspreek, waarvan die saamleef met konfessionele kompleksiteit en dinamiek 'n deurslaggewende deel vorm. ${ }^{21}$ In 1925 het die WBGK weer die vraag oorweeg of dit nodig en moontlik was om 'n universele (gemeenskaplike) Gereformeerde geloofsbelydenis aan te neem, en Barth is om sy mening gevra. Sy antwoord was 'n radikale afwysing. Een gemeenskaplike belydenis is nóg nodig nóg moontlik, het hy geredeneer, en 'n

17 Vir 'n versameling belydenisdokumente uit alle kontinente, Lukas Vischer (red.), Reformed Witness Today. A collection of confessions and statements of faith issued by Reformed Churches, Bern:

Evangelische Arbeitstelle Oekumene, 1982.

18 Sien Milan Opocenský (red.), Debrecen 1997. Proceedings of the 23rd General Council of the World Alliance of Reformed Churches (Presbyterian and Congregational), Genève: WBGK, 1997.

19 Oor Barmen, sien Karl Barth, Texte zur Barmer Theologischen Erklärung, Zürich: Theologischer Verlag, 1984; Eberhard Busch, Die Barmer These 1934-2004, Göttingen: Vandenhoeck \& Ruprecht, 2004. Oor

Belhar, sien PJ Naudé, Neither Calender nor Clock, Grand Rapids: Eerdmans, 2010.

20 Sien Odair Pedroso Mateus, "Towards an Alliance of Protestant Churches? The confessional and the ecumenical in the WARC constitutions I," Reformed World, Vol 55/1, 2005, 55-70.

21 Sien bv. Jan Rohls, Theologie reformierter Bekenntnisschriften, Göttingen: Vandenhoeck, 1987. 
beskrywing voorsien van Gereformeerde belydenisse wat wyd versprei het en invloedryk geraak het. 'n Poging deur die wêreldliggaam om 'n universele gesaghebbende belydenis af te kondig sou net mooi omtrent elke aspek van die Gereformeerde geloof, vroomheid en lewe weerspreek.

Daarom kan die Gereformeerde tradisie nie sy toevlug neem tot baie van die vorme van eenheid wat ander Christelike en selfs ander Protestantse tradisies mag hê nie - geen sentrale gesag nie, geen hiërargiese struktuur nie, geen magisterium vir leringe nie, geen korpus met onfeilbare leringe nie, geen gemeenskaplike kanon met Bybelse interpretasies nie, geen kontinue en onveranderlike liturgiese tradisie nie, geen charismatiese leierskap nie, geen basiese etniese of nasionale lojaliteit nie, geen gemeenskaplike stel godsdienstige simbole of nalatenskap met kulturele praktyke nie, geen kenmerkende soort godsdienstige ervaring nie, geen spesiale soort spiritualiteit nie, selfs nie eens een gemeenskaplike en universele boek met belydenisse nie. In plaas daarvan is dit ' $n$ tradisie wat op ' $n$ radikale manier daarop aanspraak maak dat dit daarna strewe om slegs deur "die Bybel alleen" te lewe - en dan toegee dat dit geen finale interpretasie van daardie Bybel het en geen finale gesag wat enige interpretasie kan waarborg nie, slegs ' $n$ plurale, meersinnige en dinamiese belydenistradisie.

Dit is des te interessanter omdat die Gereformeerde tradisie die eenheid van die kerk, wat inderdaad die sigbare eenheid van die kerk genoem word, baie ernstig opneem. Die tradisie was uitermate aktief in die 20ste-eeuse ekumeniese beweging en is diep besorg oor die onenigheid binne sy eie tradisie en binne die Christendom as geheel. Dit mag na 'n groot teenstrydigheid lyk, want die tradisie wys bewustelik so baie omtrent vanselfsprekende strategieë om een of ander vorm van sigbare eenheid te verkry van die hand. Die enigste pad wat dit bereid is om in te slaan, naamlik die belydende en lerende aard van die kerk, kan inderdaad lyk of dit onenigheid baie meer dien as wat dit sigbare eenheid kan bevorder. Gevolglik is die Gereformeerde tradisie diep tot sigbare eenheid verbind, maar dit worstel voortdurend met die konkrete beliggaming van hierdie eenheid. Die belydenisse het meestal in situasies van onenigheid, konflik en dreigende skeuring en verdeling ontstaan, en was meestal pogings om ' $n$ manier van sigbare eenheid vanuit hierdie konflikte te vind - soms was hulle nie suksesvol nie, en is die verdelings in geloof en lewe verdiep; baie dikwels was hulle egter inderdaad nuttig, en het hulle helderheid gebring en na hernude eenheid in geloof en lewe gelei, en deur verskeie prosesse van erkenning en aanvaarding meer en meer gelowiges verenig, soms daadwerklik oor die grense van etnisiteit en ras, sosiale status en stand, land en kontinent, tyd en ruimte.

\section{GEREFORMEERDE LERING?}

Is dit miskien moontlik om die eienskappe van die Gereformeerde tradisie in terme van lering te omskryf? Dit is gereeld probeer, maar weer eens was dit ' $n$ benadering met baie slaggate. Brian Gerrish waarsku byvoorbeeld teen die soeke na tipies Gereformeerde dogmas wat as "sogenaamde Gereformeerde kenmerke" beskou word. Wat die mees kenmerkende aan die Gereformeerde geloof is, sê hy tereg, is nie wat eie daaraan is nie, maar wat dit gemeenskaplik met ander katolieke en evangeliese gemeenskappe het. Hy haal ter illustrasie die voorwoord tot die Brief Statement of Faith van die Presbiteriaanse Kerk van die Verenigde State van Amerika (PCUSA) aan: "The faith we confess unites us with the one, universal church. The most important beliefs of Presbyterians are those we share with other Christians, and especially with other evangelical Christians who look to the Protestant Reformation as a renewal of the gospel of Jesus Christ." Dus wil Gereformeerde mense nie eiesoortige Gereformeerde leringe hê nie. Maar het hulle tog wel "essensiële leerstellinge", kenmerkende sake wat hulle eie aard beklemtoon? ${ }^{22}$

22 Sien Brian Gerrish, "Introduction: Doing Theology in the Reformed Tradition”, in Gerrish (red.), Reformed Theology for the Third Christian Millennium, Louisville: Westminster John Knox, 2003, 
Baie bekende lyste kom by 'n mens op, maar hulle weerspieël meesal baie spesifieke standpunte wat sekerlik nie deur alle ander Gereformeerde teoloë gedeel word nie. Gerrish onthou byvoorbeeld die sogenaamde Vyf Punte van Calvinisme (soms afgekort tot TULIP, 'n spesifieke Noord-Amerikaanse interpretasie van die Dordtse Leerreëls), die vyf wesenlike leerstellinge van die Algemene Vergadering van Amerikaanse Presbiteriane in 1910, tydens die fundamentalistiese geskil, en die vyf temas uit die huidige Grondwet van die PCUSA, naamlik die soewereiniteit van God en vier verwante temas (verkiesing tot redding en diens; 'n verbondslewe met gedissiplineerde besorgdheid vir orde; rentmeesterskap by die gebruik van God se gawes; die roeping om vir geregtigheid te werk).

Baie ander pogings om die basiese Gereformeerde leerstellige beklemtonings vas te lê, sou bygevoeg kon word. Die WBGK self het in 1982 'n besprekingsdokument vir sy lidkerke gepubliseer wat Called to witness to the gospel today geheet het. Die basiese verklaring was dat Jesus Christus Heer en Redder is. Deur hernude nadenke oor die Gereformeerde tradisie het hulle die heerskappy van Christus, die Skrif alleen, die sentrale rol en aard van aanbidding, prediking en die nagmaal, vryheid tot dissipelskap, en die kenmerkende orde van die kerk en die geordende bediening volgens Gereformeerde insig, bespreek. Hulle het toe in aparte afdelings op die aard van gemeenskap in Christus (insluitende die aard van die kerk as katoliek, maar ook verskeie ander sosiale kwessies van insluiting and uitsluiting, soos rassisme) gefokus, en op die getuienis van die kerk vir die evangelie in 'n bedreigte en verdeelde wêreld (insluitende kulturele diversiteit, vrede en geweld, rykdom en mag, en menseregte). Al hierdie temas kom inderdaad gereeld weer in gesprekke oor Gereformeerde identiteit voor - maar die deurslaggewende vrae oor watter standpunte eintlik ingeneem word, bly bestaan, en daaroor was die Gereformeerde gemeenskap dikwels diep verdeeld. 'n Mens hoef maar net te dink aan die gesag en interpretasie van die Skrif, die aard van die nagmaal en die funksie van kultuur, etnisiteit en ras in Gereformeerde kerke. ${ }^{23}$

Baie teoloë het ook hulle eie gesprekke oor kenmerkende Gereformeerde leerstellige beklemtonings gevoer. Ses voorbeelde is voldoende, almal van hoogaangeskrewe Gereformeerde teoloë. ${ }^{24}$ Lukas Vischer, wat lank'n leidende Gereformeerde stem in die ekumeniese wêreld was,

1-12. Vir die langer, oorspronklike dokument, sien Brian Gerrish, "Tradition in the Modern World: The Reformed Habit of Mind", in Willis en Welker (reds.), Toward the Future of Reformed Theology, Grand Rapids: Eerdmans, 1999, 3-20.

23 Called to Witness to the Gospel Today, Studies from the WARC 1 (Genève; WBGK, 1982).

24 'n Insiggewende oorsig is steeds die bundel uitgesoekte opstelle wat deur Donald K. McKim geredigeer is, Major Themes in the Reformed Tradition, Grand Rapids: Eerdmans, 1992; Eugene: Wipf \& Stock 1998. Sien ook Donald K McKim (red.), Encyclopedia of the Reformed Faith, Louisville: Westminster John Knox, 1992, en Donald K McKim (red.), The Westminster Handbook to Reformed Theology, Louisville: Westminster John Knox, 2001. Die Institute for Reformed Theology by Union Theological Seminary in Richmond, Virginia, het geleerdes van buite die tradisie genooi om hulle sienings omtrent Gereformeerde identiteit te gee, en het baie interessante response ontvang. Randall Zachman, 'n Episkopaalse geleerde oor die Reformasie, steun op Calvyn en Zwingli, asook op Edwards, Schleiermacher en Barth in sy aanspraak dat die vrygewigheid van God, die self-skenkende goedheid van God en die daaruit voortvloeiende skoonheid van God (wat gesien word in die skepping en die mensheid) "die sentrale insig" is "wat die Gereformeerde tradisie bo alle ander Christene voorhou vir hulle ernstige aandag" (in sy "The Generosity of God: The Witness of the Reformed Tradition", Lente 2006; ook sy "The Challenge and Promise of Reformed Theology", Lente 2001). Dennis Tamburello OFM beklemtoon die sentraliteit van Christus, veral die dubbele genade van regverdigmaking en heiligmaking, sowel as die vereniging met Christus, en daaruit voortvloeiend die begrip van die sakrament, die bewustheid van die Heilige Gees en die klem op dankbaarheid (in sy "Christ at the Center: The Legacy of the Reformed Tradition", Winter 2004. Al hierdie skrywes is op die webblad van die Instituut en in The Bulletin of the Institute for Reformed Theology beskikbaar. 
fokus op ses temas - maar wys in elke geval na misverstande, teenstrydighede en "veelvuldige voorbeelde van vooroordeel en verwringing" - naamlik solus Christus (maar die koninkryk van God en sy allesomvattende geregtigheid kan uit die oog verloor word), die lewende Woord (maar die sakramente word dikwels in die agtergrond geskuif), sola scriptura (met fundamentalisme wat die Gereformeerde tradisie soos 'n skaduwee volg), die klem op gemeentes en die bediening van alle gelowiges, sinodale kerkstrukture, en die oortuiging dat die evangelie op alle gebiede van die lewe van toepassing is. ${ }^{25}$

Gerhard Sauter begin met ekklesiologie (die erediens en die administrasie van die kerk), en verwys dan (meer formeel) na die rol van die Bybel en die rasionele aard van Gereformeerde teologie voordat hy (meer materieel) die bewustheid van God se soewereiniteit bespreek, die "ongewone verreikende lering van die Heilige Gees, veral van sy grenslose teenwoordigheid" en uiteindelik die "moeilike en lastige verwantskap tussen eskatologie en geskiedenis". ${ }^{26}$

Eberhard Busch begin met die "een Woord van God" as fundamentele Gereformeerde oortuiging en bespreek dan verbondsteologie, evangelie en wet, gebed en werk ('n beroep op God doen en ons roeping), die waarskuwing teen afgodediens, die kerk as gemeenskap van broeders en susters, die bediening van Jesus en die bediening in die gemeente, en die diensbaarheid ter wille van reg en vrede - en die blywende invloed van Barmen in sy verstaan van hierdie temas is onmiskenbaar. ${ }^{27}$

Michael Welker demonstreer die tipiese Gereformeerde benadering as hy die "Gereformeerde profiel" in terme van die klassieke viervoudige sola formula, naamlik Skrif alleen, Christus alleen, geloof alleen en genade alleen skets, maar in elke geval bied hy 'n baie kreatiewe, kontemporêre herinterpretasie van die dryfkrag en omvang van elke formule. ${ }^{28}$

Jane Dempsey Douglass, 'n voormalige president van die WBGK, beskryf Gereformeerde teologie as "katolieke nadenke wat gefokus is op wat God doen en hoe God ons roep om deel te neem aan God se werk", as "wat gedoen word in, met en vir belydende Christelike gemeenskappe en vir die wêreld." Volgens haar is dit "nie 'n geskrewe liggaam wat in die verlede afgehandel is nie, maar ' $n$ tradisie wat teologie op die Gereformeerde manier doen, sekerlik in voortsetting van die klassieke Gereformeerde teoloë en die belydenisse, maar steeds in wording, steeds onvoltooid, en wat tot aan die einde van die tye so sal wees." ${ }^{29}$ Met verwysing na die leerstelligee taak van Gereformeerde kerke vandag, wys sy op die noodsaak om die solidariteit van Christus met die mensdom opnuut te oordink, die solidariteit van die mense van Christus en die solidariteit van die menslike familie wat volgens die beeld van God geskep is. ${ }^{30}$ Dit is duidelik dat sy bewustelik 'n denkwyse beskryf eerder as die leerstellige inhoud van die tradisie.

Vanuit 'n Suid-Afrikaanse perspektief bespreek John de Gruchy sentrale Gereformeerde oortuigings in sy Warfield-lesings, wat dubbelsinnig Liberating Reformed theology genoem word. Hy gebruik sy landgenoot Lekula Ntoane se woord, "a cry for life", as motto vir die Gereformeerde geloof en die bevrydende potensiaal daarvan. Hy behandel dan die Gereformeerde siening van die Skrif (en bevryding van die tirannie van tradisie, gewoonte en filosofie), die siening van

25 Lukas Vischer, "The Reformed Church and its Witness Today”, in Confessing Jesus Christ in Dialogue, Genève: John Knox, 1986, 19-34.

26 Gerhard Sauter, "Observations on the Current State of the Reformed Theology", op die webblad van die Institute for Reformed Theology, Herfs 2004.

27 Eberhard Busch, Reformiert. Profil einer Konfession (Zürich: TVZ, 2007).

28 Michael Welker, "Reformation Theology and the Reformed Profile", The Bulletin of the Institute of

Reformed Theology, Winter 2003, nr. 1. Sien ook Berndt Hamm en Michael Welker, Die Reformation.

Potentiale der Freiheit, Tübingen: Mohr Siebeck, 2008.

29 Jane Dempsey Douglass, “What is 'Reformed Theology'?”, The Princeton Seminary Bulletin, 1990.

30 Jane Dempsey Douglass, “A Theme for Today's Reformed Theologians”, The Bulletin of the Institute of Reformed Theology, Lente 2000. 
God (en bevryding van afgodediens, wat die "tirannie van menslike krag is wat optree asof dit goddelik is"), die siening van soteriologie (en bevryding deur genade alleen van die tirannie en verskrikking van slegte godsdiens), die siening van die kerk (en bevryding van die tirannie van menslike tradisie en onwaarheid) en die siening van die rol van die kerk in die samelewing (met die politieke taak van die kerk in diens van bevryding van tirannie en anargie). ${ }^{31}$

Ten spyte van al die verskille is dit duidelik dat sommige van hierdie leerstellige temas herhaaldelik in baie van die diskussies voorkom, sodat hulle inderdaad in die geheel as 'n korpus oortuigings van besondere belang vir die Gereformeerde geloof beskou kan word. Dit is egter ook duidelik dat etiese temas, die praktiese implikasies vir die Christelike lewe, ook telkens weer opduik. Daarom is dit miskien beter om nie na die Gereformeerde identiteit in besondere leringe te soek nie, maar om dit liewer te sien as 'n manier om 'n Christelike gemeenskap in die wêreld te wees, coram Deo. Hierdie formule sluit aan by wat John Leith aan die hand doen in sy nuttige Introduction to the Reformed Tradition, want dit vestig die aandag op wat hy die omvattende etos van die Gereformeerde tradisie noem, wat teologie sekerlik ook insluit, maar ook organisatoriese vorme, liturgie en kultuur. Miskien moet 'n mens sê Gereformeerde vroomheid is ' $n$ bewustheid van in die geskiedenis lewe en in die wêreld voor die aangesig van die lewende God. ${ }^{32}$

Gerrish formuleer ' $n$ soortgelyke oortuiging op ' $n$ ander manier. In plaas van 'n lys "permanente dogmas", redeneer hy, moet 'n mens aandag gee aan die tipies Gereformeerde "gewoonte van ingesteldheid". Hy bespreek dan vyf kenmerke van die Gereformeerde gewoonte van ingesteldheid, naamlik dat dit eerbiedig is (deferential, respekvol, vol eerbied, as beskrywing van die tipies Gereformeerde verstaan van tradisie); basies krities (nie onnadenkende nabootsing nie); óóp (vir wysheid en waarheid waar dit ook al te vinde is, en daarom ook vir volledig vrye wetenskaplike ondersoek en vir "wat vir die kerk gesê word" deur die buitewêreld van geleerdheid); prakties (omdat waarheid "lei tot" goedheid, impliseer dit dat stigting, heiligmaking en transformasie belangrik is, eerder as spekulasie en nuuskierigheid), en evangelies. Opsommend beweer hy daarom: "Reformed theology is an ongoing conversation into which the 'fathers' of the Reformed church are drawn, deferentially but not uncritically; in which openness to sacred and secular learning brings continual new light, always with an eye to the practice of piety and the transformation of human lives, both individually and socially; and in which, finally, the focus returns again and again to the gospel." 33

\section{GEREFORMEERDE LEWE?}

Die Gereformeerde tradisie is duidelik ook bekend vir sy klem op die Christelike lewe, op moraliteit en etiek, vanaf die persoonlike tot by die politieke. In die meeste van hierdie beskrywings kom die integrale verband tussen geloof en lewe na vore. Calvyn self het alreeds die begin van verskeie kenmerkende trajekte binne die Gereformeerde lewe verteenwoordig. Hy was besorg oor die implikasies van die geloof vir die lewe, van lering vir etiek. Sy vernaamste boek was immers oor onderrig in die Christelike lewe, dit wil sê in vroomheid en die volle praktiese implikasies vir die Christelike lewe. Sy besorgdheid was dat die evangelie suiwer verkondig moes word maar "ook gehoor" word. Hy was in die eerste plek 'n pastor, en deur sy baie aktiwiteite en geskrifte - gereelde preke, kommentare, lesings, Bybelstudies, duisende briewe, traktate en pamflette, maar ook deur sy betrokkenheid in die openbare lewe, plaaslike en internasionale politiek,

31 John W de Gruchy, Liberating Reformed Theology, Grand Rapids: Eerdmans, 1991. Hy verwys na

Lekula Ntoane, A Cry for Life. An Interpretation of 'Calvinism' and Calvin, Kampen: Kok, 1983.

32 John H Leith, Introduction to the Reformed Tradition, Atlanta: John Knox, 1978.

33 Gerrish, "Tradition in the Modern World: The Reformed Habit of Mind," in David Willis \& Michael

Welker, Toward the Future of Reformed Theology, Grand Rapids; Eerdmans, 1999, 3-21. 
gemeenskapsdiens, armoedeverligting, gesondheidskwessies, opvoeding en regsake - het hy probeer om diens te lewer aan wat hy gesien het as die Christelike lewe.

Ten diepste was sy oortuiging dat ons nie aan onsself behoort nie ' $n$ vorm van kennis wat sowel volledige vertroosting bied as wat dit volledige eise stel. Party mense beskou hierdie oortuiging as die opsomming van Gereformeerde etiek. Dit is die onderwerp van die Heidelbergse Kategismus (1563), die sleutel tot die Teologiese Verklaring van Barmen (1934), die openingsmotief in die Brief Statement of Faith (1993) van die PCUSA en die herhalende refrein van die Debrecenlitanie (1997) wat deur die WBGK opgestel is met die oog op ekonomiese onreg en ekologiese vernietiging. Weer eens het hierdie oortuiging baie omstrede geraak. Vrae oor selfliefde, selfontkenning en selfopoffering, hetsy persoonlik en individueel of gemeenskaplik en kollektief, byvoorbeeld wat betref nasie en land, het dikwels tot intense debatte gelei. Gereformeerde etiek is dikwels daarvan beskuldig dat dit 'n pessimistiese antropologie en 'n ongesonde minagting vir selfvervulling en geluk het. Vrae en konflikte oor evangelie en wet, die sogenaamde derde gebruik van die wet, regverdigmaking en heiligmaking, genade en dankbaarheid, geroepenheid en roeping, vryheid en verantwoordelikheid, het kenmerkend geword. Gereformeerde etiek is dikwels van moralisme en wettisisme beskuldig.

Calvyn het hierdie vertroosting en eise op ' $n$ Trinitariese manier ontwikkel, wat tot 'n komplekse beskrywing van die Christelike lewe lei. Etiese temas verskyn in verskillende teologiese kontekste in sy werk, wat aanleiding gee tot latere debatte, omdat verskillende historiese figure ná hom verskillende trajekte uit sy werk beklemtoon het. Ten minste drie sulke kontekste in sy omvattende werk het invloedryke resepsie-geskiedenisse belewe.

Eerstens behandel hy, in die kern van sy gesprek oor ons kennis van God as genadige en soewereine Vader, God se morele wet, en redeneer hy dat die morele wet opgesom is in die Tien Gebooie (Institusie II, 8). Hy soek na positiewe bedoelings agter elk van die gebooie, en pas hulle op etiese kwessies van sy tyd toe. In die Gereformeerde geskiedenis sou hierdie benadering invloedryk word. Dit sou ook kontroversiële vrae oor benaderings tot etiek vanuit natuurwette stel en die noodsaaklikheid vir die Skrif in ons pogings om die goddelike morele wet te onderskei en leer ken. Van spesiale belang sou sy bewerings oor die waardigheid van alle mense, ongeag wie hulle is, wees, want ons herken die beeld van God en ons eie vlees tegelykertyd in almal van hulle.

Tweedens beskryf hy die Christelike lewe as hy ons kennis van God die Verlosser in Jesus Christus bespreek. Hier verbind hy regverdigmaking en heiligmaking (Institusie III, 6-10) met mekaar. Alreeds in sy eie tyd is hierdie afdelings apart gepubliseer en het hulle' $n$ belangrike bron en inspirasie vir Gereformeerde etiek geword, vir baie mense eenvoudig die mees informatiewe en gesaghebbende beskrywing van die Christelike lewe wat beskikbaar is.

Derdens het hy 'n invloedryke uitbeelding van "Christelike vryheid" gegee (Institusie III, 9), oorspronklik bedoel as inleiding tot sy diskussies van kerklike regeringsvorme sowel as burgerlike regering. Sowel sy begrip van die sigbare vorm, struktuur en orde van die kerk as sy begrip van politieke en openbare lewe rus daarom op sy begrip van vryheid, en weer eens sou dit vormende tradisies in Gereformeerde etiek word. In navolging van Luther se twee stellinge (oor die vryheid van ' $n$ Christen-mens), voeg hy' $n$ verreikende derde stelling by wat oor die adiaphora handel, en argumenteer hy ten gunste van vryheid om neutraal te wees teenoor baie menslike, kulturele, kerklike en godsdienstige verpligtinge, dit wil sê, vir die vryheid om neutraal te wees teenoor die neutrale. Baie van die teenstrydighede in Calvyn se nalatenskap sou gaan oor die vraag oor wat as neutraal beskou kan word. Dié selfkritiese houding (van die semper reformanda) sou dikwels Gereformeerde gelowiges van gevestigde praktyke en institusionele vorme bevry wat deur andere as goddelik bestem en onveranderlik beskou is. Barth sou evangeliese etiek as ' $n$ etiek van vryheid beskryf. 
Hierdie drie verskillende benaderings het gevolglik tot die veelduidige en omstrede resepsiegeskiedenis bygedra. Sommige sou 'n etiek primêr op die basis van die morele wet bou en begrippe soos natuurwette, algemene openbaring en algemene genade gebruik, sommige sou op meer persoonlike etiek konsentreer, dikwels individualisties, met die klem op dissipelskap, oordenking, gebed en selfverloëning, nog andere sou ten gunste wees van sosiale etiek en openbare verantwoordelikheid in politiek, ekonomie, opvoeding, die regswese, publieke opinie en kulturele vorming.

Dit is alreeds duidelik waarom enige kort historiese oorsig onmoonlik is. 'n Paar verteenwoordigende illustrasies - neigings, episodes, figure - kan wel dalk tipiese ontwikkelings en kenmerke belig. Sedert die vroegste tye het onderrig ' $n$ vormende rol in die Gereformeerde vroomheid en lewe gespeel, hetsy deur kategismusse, preke en geskrifte. Die toepassing van die Tien Gebooie as 'n morele wet was gewild. Verklarende preke was waarskynlik die belangrikste dissipline en praktyk van Gereformeerde etiek. Andre Bieler het byvoorbeeld 'n vermaarde studie van Calvyn se sosiale en ekonomiese denke gemaak deur sy preke te ontleed. ${ }^{34}$

Die eerste etiek in die nalatenskap van Calvyn is deur ' $n$ regsgeleerde, Lambertus Danaeus (1577) geskryf. In baie opsigte het dit ' $n$ insiggewende illustrasie geword van wat later sou gebeur. Die humanistiese agtergrond wat alreeds in Calvyn teenwoordig was, is nou selfs verder ontwikkel, saam met verskillende filosofiese invloede, vanuit Aristoteles sowel as die Stoïsisme - kenmerkend van humanistiese en filosofiese invloede later. Die veranderende houding van die tyd, naamlik 'n sterk bewustheid van sosiale krisis en 'n besef van die sosiale orde wat uitmekaar val, en gevolglik die dringende noodsaak vir 'n nuwe sosiale orde en heropbou, speel 'n deurslaggewende rol in die noodsaak vir so 'n Gereformeerde etiek - soos wat dikwels weer in die geskiedenis sal gebeur as sosiale krisisse om nuwe en selfkritiese etiese projekte vra. In die werk self kombineer sy regsopleiding en belange met fundamentele teologiese besluite en oortuigings - weer tipies van latere ontwikkelings. ${ }^{35}$ Gereformeerde denke sou op belangrike maniere bydra tot die skeiding tussen kerk en staat en die ontwikkeling van 'n regstelsel en regterlike mag wat op menswaardigheid en menseregte gebaseer is, ${ }^{36}$ en onafhanklik van die invloed van die institusionele kerk en godsdiens is. ${ }^{37}$

Sedert die begin van die moderne tydperk en Schleiermacher se meer filosofiese etiek het die nuttige onderskeid tussen drie etiese benaderings - wat onderskeidelik op goedheid (waardes, morele oortuigings), deugde (karakter, morele agentskap) en pligte (norme, reëls, beginsels, besluite) fokus - gewild geword. Verskillende etiese tradisies en etici binne die Gereformeerde geloof sou verskillende voorkeure hê en gevolglik op verskillende maniere ontwikkel. Sommige fokus op breër visies en sienings van die wêreld, andere konsentreer op die persoonlike lewe van gelowiges as morele agente, sommige konsentreer op morele besluite en die rol van norme en reëls. Elke tradisie sou die Skrif dienooreenkomstig lees. Afhangende van 'n mens se eie agtergrond en ervaring vereenselwig baie mense Gereformeerde etiek met enige een van hierdie drie benaderings tot etiek en die dienooreenkomstige rol van die Skrif, maar in werklikheid was al drie van hulle dominant in die Gereformeerde geskiedenis, soos wat deur verskillende gemeenskappe gedemonstreer is.

'n Paar illustrasies sal voldoende wees. In Nederland het Kuyper 'n omvattende lewens- en wêreldbeskouing ontwikkel wat 'n blywende impak op die kultuur en spesifieke subkulture in baie dele van die wêreld sou hê. ${ }^{38}$ In Suid-Afrika was hierdie nalatenskap byvoorbeeld belangrik

34 André Bieler, Calvin's Economic and Social Thought, Genève: WARC, 2006.

35 Christoph Strohm, Ethik im frühen Calvinismus, Berlyn: De Gruyter, 1996.

36 John Witte, The Reformation of Rights, Cambridge: Cambridge University, 2007.

37 Christoph Strohm, Calvinismus und Recht, Tübingen: Mohr Siebeck, 2008.

38 Peter S Heslam, Creating a Christian Worldview, Grand Rapids: Eerdmans, 1998. 
in die regverdiging van die wêreldbeeld van apartheid en die politieke stelsel sowel as in die stryd téén hierdie ideologie. ${ }^{39}$ Op dikwels uiteenlopende maniere het invloedryke publieke teoloë en etici in Noord-Amerika, soos Reinhold Niebuhr, H Richard Niebuhr, Paul Lehmann en meer onlangs James Gustafson almal hulle bydraes gelewer vanuit die tradisie van Gereformeerde etiek. Gustafson neem byvoorbeeld drie ideologiese leerstellings uit die Gereformeerde tradisie, naamlik die bewustheid van ' $n$ magtige Ander (in Calvinistiese terme die soewereiniteit van God), die sentraliteit van vroomheid of godsdienstige toegeneentheid in die morele lewe (vir hom die Calvinistiese toegeneenthede van afhanklikheid, dankbaarheid, verpligting, berou, moontlikheid en rigting), en die erkenning dat alle menslike aktiwiteit georden behoort te word met betrekking tot dit wat onderskei kan word omtrent die doelstellinge van God (dit is waarom hy sy etiek "teosentries"noem, in die laaste instansie gebaseer op "teologie as 'n manier om die wêreld te vertolk"). ${ }^{40}$ Vanuit die Duitssprekende Gereformeerde wêreld het Barth weer 'n groot invloed uitgeoefen. Hoewel sommige, as hulle aan sy vroeëre werke dink, sy etiek as ' $n$ vorm van arbitrêre besluitneming beskou, kan dit meer paslik verstaan word as 'n omvattende poging om die siening van die "morele ontologie" van die Skrif ernstig op te neem. ${ }^{41}$ Van Engeland af tot in die Verenigde State het die Puritanisme ' $n$ vormende openbare krag geword; uit verskeie Europese gemeenskappe het verskeie vorme van Gereformeerde Piëtisme na baie ander kontinente versprei; terwyl die komplekse verskynsel van Evangelikalisme op baie maniere verstaan moet word met betrekking tot Gereformeerde wortels en invloede. Vandag het Gereformeerd, Calvinisties en neo-Calvinisties almal baie gesigte.

\section{GEREFORMEERDE ETIEK?}

Hoewel dit moeilik en kontroversieel is in die lig van die uiteenlopendhede, is dit miskien legitiem om te veralgemeen en 'n paar gemeenskaplike kenmerke van Gereformeerde etiek op te noem.

Eerstens is dit alreeds tipies dat etiek so sentraal is. Die belangstelling in die Christelike lewe - in dissipelskap, in heiligmaking, in die derde gebruik van die wet, in die respek vir menswaardigheid, in roeping, in gelofte, in gemeenskapslewe, openbare verantwoordelikheid, politieke deelname, in kwessies van vryheid en geregtigheid, in demokratiese lewe en sosiale welsyn, in kultuur, geleerdheid, opvoeding - behoort integraal tot die Gereformeerde gesigspunt.

Dit is in die tweede plek kenmerkend dat hierdie passie vir etiek voortvloei uit teologiese, leerstellige, geloofs- of belydenisoortuigings. Daar is opmerklike uitsonderings, maar die geheelprentjie is eerder dat lering en geloof integraal verbind is. Dit dra daartoe by dat etiese sienings so uiteenlopend is. Hulle is gebaseer op uiteenlopende sienings van God en uiteenlopende maniere om die Skrif te verstaan. Barth en Gustafson bied dramatiese voorbeelde. Terwyl Gustafson volledig met Barth saamstem oor die deurslaggewende belang van die lering van God vir etiek, verskil hy radikaal van Barth se eiesoortige siening van God (naamlik dat Hy in Christus openbaar is en daarom Drie-enig is en redding bewerk). Die spektrum van teologiese moontlikhede is ryk en kompleks - vanaf klem op God as Skepper en wetgewer, tot klem op Jesus Christus, tot klem op die werk van die Heilige Gees, en binne elkeen van hierdie beklemtonings is die moontlikhede om hulle op verskillende maniere te verstaan weer eens omtrent onbeperk en weer eens word die Skrif gebruik op al hierdie uiteenlopende maniere om die beeld van God te ondersteun en daarmee etiese perspektiewe en oriëntasie te verskaf.

39 Allan A Boesak, The Tenderness of Conscience, Stellenbosch: SunMedia, 2005; Dirk J Smit, Essays on

Being Reformed. Collected Essays 3, Stellenbosch: SunMedia, red. Robert R Vosloo, 2009, veral 185294.

40 James M Gustafson, Ethics from a Theocentric Perspective, 2 bundels, Chicago: Universiteit van

Chicago, 1981-1984.

41 John Webster, Barth's Moral Theology, Grand Rapids: Eerdmans, 1998. 
Derdens verwys die begrip "Gereformeerd" na die selfkritiese bewustheid en die voortdurende gewilligheid dat opnuut ondersoek moet word en indien nodig getransformeer moet word in die lig van die Skrif. Hierdie selfbegrip het Gereformeerde etiek diepgaande histories en kontekstueel gemaak. Dit reageer op nuwe uitdagings in die geskiedenis en kan dramaties deur sulke uitdagings verander word. Etiese oortuigings en praktyke word as tydelik beskou, vir nou en voorlopig, nooit finaal en ewig nie, gebaseer op huidige insig. Dit het tot gevolg dat begrippe soos verantwoordelikheid (Richard Niebuhr), geroepenheid ("hier en nou"), die waarneming van God se wil (die vroeë Barth), die lees van en reaksie op die konteks (Lehmann) dikwels populêr is - almal begrippe wat die historiese verantwoordelikheid om waar te neem en te reageer onderstreep, eerder as begrippe van gehoorsaamheid aan gesag of lojaliteit aan dit wat alreeds vooraf besluit is. ${ }^{42}$

Vierdens is dit kenmerkend dat die deurlopende hernuwing volgens die Skrif na die hernuwing van gelowiges kan verwys, na die kerk of na die samelewing. Om praktiese implikasies deur te trek vir al drie - vir die persoonlike lewe, vir die sigbare struktuur en lewe van die kerk, en vir die sfere van politieke en openbare lewe - was altyd integraal vir die Gereformeerde geloof en etiek. Die boodskap van die Skrif kan op baie verskillende maniere verstaan word ten einde die nodige oriëntasie vir die beliggaming te verskaf, hetsy in die individuele lewe, in die kerk of in die samelewing. Populêre Gereformeerde motiewe sluit die heerskappy van Jesus Christus oor die hele werklikheid in, soms geformuleer as die sogenaamde profetiese rol van die kerk. So 'n profetiese houding is dikwels gedemonstreer deur betrokkenheid by die bevordering van sosiale geregtigheid, en is tipies van die WBGK sedert sy stigting tot met die bekende Accra-Verklaring (2004) insake globale ekonomiese onreg en uitsluiting en wydverspreide ekologiese vernietiging.

In die laaste plek word Gereformeerdes meermale beskryf as "mense van die Boek" om die belangrikheid van die Skrif in hierdie tradisie te onderstreep. Die twee belangrikste praktyke in die tradisie was waarskynlik die weeklikse erediens waar die Skrif en in die besonder uitleg en onderrig inderdaad 'n sentrale plek ingeneem het, asook die oordenkende lees, bestudering en bespreking van die Skrif, hetsy privaat, as gesin, of saam met ander. Die Skrif word as gesaghebbend beskou, dikwels beskryf as die "Woord van God", en dit sluit die Ou Testament ook in. Deur die gesag van die hele Skrif vir die geloof en lewe te bely, lê die Gereformeerde tradisie as geheel sekere onderskeidende aksente wat 'n bevestiging van die noodsaak vir interpretasie insluit; die beklemtoning van die belangrikheid van wetenskaplike eksegese; aandag aan die Skrif as geheel; erkenning van 'n sekere vorm van skopus, gerigtheid of boodskap; respek vir die rol van tradisie; die baie ernstige opneem van die gemeenskap van die gelowiges; die siening van prediking, onderrig en studie as sentraal vir die opbou van die geloof; die beklemtoning van die openbaring van die Heilige Gees; en die beklemtoning van verskeidenheid sowel as eenheid in die Skrif. ${ }^{43}$

\section{TREFWOORDE}

Gereformeerde identiteit

Gereformeerde belydenis

Gereformeerde leer

Gereformeerde lewe

Gereformeerde etiek

\section{KEY WORDS}

Reformed identity

Reformed confession

Reformed doctrine

Reformed life

Reformed ethics

42 Sien byvoorbeeld Doug Schuurman, Vocations. Discerning our Callings in Life, Grand Rapids:

Eerdmans, 2004.

43 Uit 'n belangrike rapport oor "Hermeneutics and Ethics", Grand Rapids: Gereformeerde Ekumeniese Raad, 1992. 